\title{
Removal of Iron Oxide from Indoor Air at a Subway Station Using a Vegetation Biofilter: A Case Study of Seoul, Korea
}

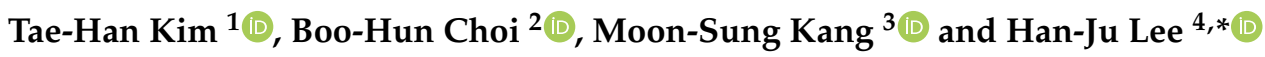 \\ 1 Department of Green Smart City, Sangmyung University, 31 Sangmyungdae-gil, Dongnam-gu, \\ Cheonan-si 31066, Chungcheongnam-do, Korea; taehankim@smu.ac.kr \\ 2 Department of Environmental Resource, Sangmyung University, 31 Sangmyungdae-gil, Dongnam-gu, \\ Cheonan-si 31066, Chungcheongnam-do, Korea; smb202a@gmail.com \\ 3 Department of Green Chemical Engineering, Sangmyung University, 31 Sangmyungdae-gil, Dongnam-gu, \\ Cheonan-si 31066, Chungcheongnam-do, Korea; solar@smu.ac.kr \\ 4 Department of Nursing, Sangmyung University, 31 Sangmyungdae-gil, Dongnam-gu, \\ Cheonan-si 31066, Chungcheongnam-do, Korea \\ * Correspondence: dalbich@smu.ac.kr
}

Citation: Kim, T.-H.; Choi, B.-H.; Kang, M.-S.; Lee, H.-J. Removal of Iron Oxide from Indoor Air at a Subway Station Using a Vegetation Biofilter: A Case Study of Seoul, Korea. Atmosphere 2021, 12, 1463. https://doi.org/10.3390/ atmos12111463

Academic Editor: Boris Igor Palella

Received: 3 October 2021

Accepted: 3 November 2021

Published: 5 November 2021

Publisher's Note: MDPI stays neutral with regard to jurisdictional claims in published maps and institutional affiliations.

Copyright: (c) 2021 by the authors. Licensee MDPI, Basel, Switzerland. This article is an open access article distributed under the terms and conditions of the Creative Commons Attribution (CC BY) license (https:/ / creativecommons.org/licenses/by/ $4.0 /)$.

\begin{abstract}
Recently, metallic particulate pollutants floating underground have been reported to negatively affect the human body. Thus, there is an urgent need for a public health policy pertaining to the air quality in subway stations. In this study, we investigated whether a vegetation biofilter is effective in reducing metal particle contaminants, especially iron oxide. After selecting a subway station, a vegetation biofilter system was installed, and samples were collected three times, at three intake areas and one exhaust area. The average weight ratio of the detected elements was calculated. The iron oxide reduction effect was evaluated using the Wilcoxon signed rank test. In the return air, $\mathrm{C}, \mathrm{O}$, and Fe were detected at $64.9,27.3$, and $5.2 \mathrm{wt} . \%$, respectively; in the supply air, $\mathrm{C}, \mathrm{O}$, and Fe were detected at $67.2,30.4$, and $0.7 \mathrm{wt} . \%$, respectively. The difference in the average Fe weight ratio was statistically significant. Air quality has a considerable effect on human health. We confirmed the possibility of reducing Fe in particulate matter using biofilters. However, we could not confirm whether the air quality was improved enough to not have a negative effect on the human body. This should be elucidated through follow-up studies.
\end{abstract}

Keywords: metallic particulate pollutant; subway station; vegetation biofilter; iron oxide

\section{Introduction}

The particulate matter (PM) present in polluted air has been classified as a first-tier carcinogen by the International Cancer Research Institute of the World Health Organization (WHO) since 2013 [1]. The amount of PM in different areas is as follows: $81.2 \mu \mathrm{g} / \mathrm{m}^{3}$ in indoor parking lots, $69.4 \mu \mathrm{g} / \mathrm{m}^{3}$ in underground stations, $56.9 \mu \mathrm{g} / \mathrm{m}^{3}$ in large-scale stores, $54.8 \mu \mathrm{g} / \mathrm{m}^{3}$ in personal computer rooms, and $50.6 \mu \mathrm{g} / \mathrm{m}^{3}$ in private institutes; a large amount of fine dust is generated underground [2]. PM found in subway stations is considered to be considerably more dangerous than PM detected from other sources (wood combustion, vehicular traffic, and roadways), owing to the redox-active iron deposited on the particles [3,4]. In the atmosphere of underground stations, aerosol-type particles containing iron account for $75 \%-85 \%$ of the total PM. These iron components are generated by mechanical phenomena such as friction and scratches between rails and wheels, after which they float in the air and react with oxygen in the atmosphere to form iron oxides (e.g., $\mathrm{Fe}_{3} \mathrm{O}_{4}, \alpha-\mathrm{Fe}_{2} \mathrm{O}_{3}$, and $\gamma-\mathrm{Fe}_{2} \mathrm{O}_{3}$ ), which are diffused into the underground space by train winds [5]. In nature, iron oxides commonly exist as mixtures. Iron oxides are useful in various fields, for example, drug delivery, magnetic resonance imaging, soil and groundwater remediation, and photocatalysis [6,7]. Artificial generation of iron oxide contaminants and the subsequent inhalation into the human body lead to cytotoxicity, oxidative stress, genotoxicity, and DNA damage in lymphocytes [8,9], as well as pathological conditions, such as 
tissue inflammatory response [10] and cancer [11]. Additionally, iron oxide nanoparticles, produced by friction between rails and wheels, have negative effects because their small size allows them to easily penetrate biological membranes [12]. Maher et al. [13] suggested that the magnetic iron oxide found in the brain of patients with Alzheimer's disease was not a product of natural brain activity, but rather an artificial pollutant generated by frictional heating during transportation. According to Maher et al., iron oxide generated from subway operations is inhaled through the mouth and nose, passes through the olfactory nerve or the trigeminal nerve, and then accumulates in the brain tissue. The accumulation of iron oxide has been suggested to cause neurodegenerative diseases [14] such as Alzheimer's disease [15,16] and Parkinson's disease [17] through long-term deformation of the nervous system. Furthermore, the exposure of pregnant women to environmental pollutants such as iron oxide during pregnancy has been demonstrated to negatively affect the health of newborns $[18,19]$. Thus, there is an urgent need to develop countermeasures to protect public health against the polluted air in underground stations.

Stephens et al. evaluated the performance of commercially available MERV 4-6, MERV 10-11, MERV 13, and MERV 16 filters for air conditioning systems and reported that the removal efficiency of MERV 4-6 and MERV 10-11 used in residential environments was only $0 \%-10 \%$ and $15 \%-20 \%$ [20]. The interest in the utility of plants as a sustainable and eco-friendly substitute has been increasing along with the argument that heating, ventilation, and air conditioning (HVAC) systems are ineffective because PM is only partially removed [21]. Furthermore, in Korea, the usage of chemical components in products, such as antibacterial filters and humidifier disinfectants, has highlighted the negative effects associated with poor indoor air quality (IAQ). Plants are considered safe alternatives for air purification because they are environmentally friendly and sustainable and remove indoor air pollutants. Several studies on optimizing the air purification performance of plants in relation to the air conditioning systems have been conducted [22-25]. Moreover, other studies have shown that the filtering function of plants could reduce indoor pollutants (e.g., formaldehyde, toluene, and benzopyrene) $[21-23,26,27]$. However, air-purifying plants operate by adsorbing PM [28], and a study [29] has reported that the cleaning ability of leaves is necessary for continuous PM removal. Biofilter systems that increase PM removal efficiency by linking air-purifying plants with air conditioning facilities are drawing attention because they help to overcome the aforementioned challenge. Mechanistically, a biofilter adsorbs gases present in indoor polluted air, following which the gases are decomposed upon passing through base materials such as plants [30]. Soreanu et al. (2013) classified biofilters that use plants into passive and active types [31]. In the passive type, the plants act as a passive biofilter, wherein pollutants are removed by supplying water or nutrients occasionally. In the active type, pollutants are removed using a plant-assisted biotrickling filter that is connected to a hydroponic system and plant root zone support material; there is a continuous supply of nutrients and passage of air. In this study, an active-type vegetation biofilter system was used. Studies have been conducted on the particulate pollutant (arising from diesel fuel combustion) removal efficiency of vegetation biofilters [21]; the effects of vegetation biofilters on PM concentrations, carbon dioxide levels, and indoor comfort indices [30]; and PM removal efficiency of vegetation biofilters in the lecture rooms of universities, which are environments with continuous emissions of particulate pollutants [32]. Vegetation biofilter systems are expected to be useful as an eco-friendly purification method to improve air quality in the future. As the number of multi-use facilities in densely populated cities is increasing, IAQ management has become an important public health concern. In particular, air quality management is essential, as the generation of metallic particulate pollutants in underground stations, which are representative multi-use facilities, has negative effects on individuals who inhale these pollutants. Therefore, in this study, we explored the possibility of reducing iron oxide, a representative pollutant, after installing a vegetation biofilter system-a non-chemical air purification method-in an underground station in a large city. 


\section{Materials and Methods}

\subsection{Target Site}

The target site was selected considering the representativeness and frequency of use. The station has an average daily floating population of 51,267 tourists who visit cultural assets, including the cultural heritage and surrounding tourism resources. The station consists of three underground floors, with a total floor area of $12,214 \mathrm{~m}^{2}$; the first floor is used as an exhibition space, the second floor is the ticket gate, and the third floor is the platform. This study was conducted in the waiting room in the second basement floor. The ticket gates are divided into three locations, and each ticket gate is connected to the train platform via stairs or escalators.

\subsection{Experimental Environment and Conditions}

\subsubsection{IAQ Station}

To monitor the IAQ of the study site, six IAQ sensor stations with entry-model sensors (Smart Aircork, Aircork, Korea) were installed by dividing the stair or escalator area connected to the platform (\#1,\#3, and \#6) and the ticket gate area (\#2,\#4, and \#5). The measuring instrument supports time series monitoring of $\mathrm{PM}_{2.5}$ and $\mathrm{PM}_{10}$ concentrations, temperature, and humidity (Table 1). In addition, data transmission and reception are more stable than WiFi using an LTE-based communication method. The instrumentation reliability of the IAQ stations was comparable to that of the reference equipment (AM520; TSI, Dallas, TX, USA).

Table 1. Sensor specifications for indoor air quality stations.

\begin{tabular}{ccc}
\hline Sensor & Method & Range \\
\hline $\mathrm{PM}_{2.5} / \mathrm{PM}_{10}$ & Light scattering method & $0-6000 \mu \mathrm{g} / \mathrm{m}^{3}$ \\
Temperature & Semiconductor band gap type & -40 to $125{ }^{\circ} \mathrm{C}$ \\
Relative humidity & Capacitive polymer & $0-100 \%$ relative humidity \\
\hline
\end{tabular}

\subsubsection{Selection of Mockup Construction Location}

Preliminary monitoring of indoor air quality in the waiting room in the second basement floor of the subway station was carried out from 15 November 2019 to 31 December 2019 for the mockup construction of the vegetation biofilter (Table 2). The particulate matter concentration in areas \#5 and \#6, where floating populations are concentrated, was relatively high among the six areas. The $\mathrm{PM}_{10}$ concentration in area \#6 was the highest $\left(69.2 \mu \mathrm{g} / \mathrm{m}^{3}\right)$, and the $\mathrm{PM}_{2.5}$ concentration in area \#5 was the highest $\left(47.8 \mu \mathrm{g} / \mathrm{m}^{3}\right)$.

Table 2. Sensor specifications for indoor air quality stations.

\begin{tabular}{cccccccc}
\hline Pollutant & & \#1 & \#2 & \#3 & \#4 & \#5 & \#6 \\
\hline \multirow{4}{*}{ PM $_{10}$} & Mean & 40.4 & 48.8 & 42.1 & 46.8 & 63.5 & 69.2 \\
& SD & 24.2 & 31.1 & 28.2 & 32.2 & 31.1 & 36.2 \\
& Max & 203 & 253 & 185 & 205 & 220 & 260 \\
& Min & 5 & 8 & 7 & 7 & 7 & 5 \\
\hline \multirow{4}{*}{ MM $_{2.5}$} & Mean & 29.7 & 36.3 & 31.1 & 34.8 & 47.8 & 36.7 \\
& SD & 18.6 & 24.5 & 21.7 & 25.2 & 25.3 & 20.1 \\
& Max & 173 & 214 & 148 & 171 & 184 & 148 \\
& Min & 4 & 6 & 5 & 5 & 5 & 3 \\
\hline
\end{tabular}

Therefore, area \#6 was selected as the vegetation biofilter mockup construction site between areas \#5 and \#6, areas where the maximum concentration of fine dust is expected to be collected, considering the movement of passengers (Figure 1). 


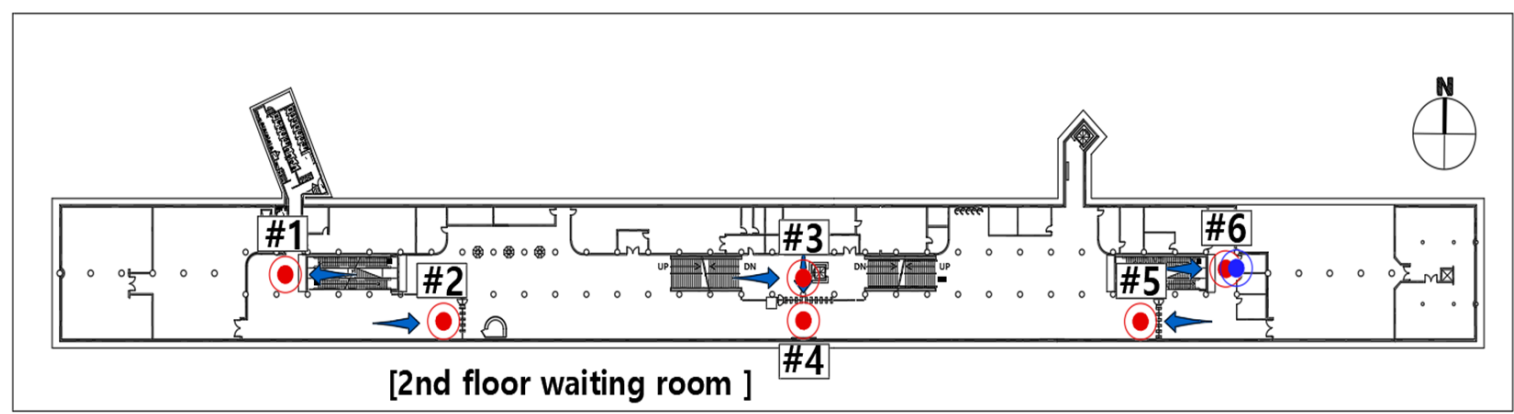

o Point of IAQ Station Installation -IAQ Station Intake Direction - Location of Vegetation Biofliter installation

Figure 1. Installation area of the mockup biofilter.

\subsubsection{Vegetation Biofilter System}

The vegetation biofilter system used in this study was a vertical hydroponic structure composed of a single panel. This system provides an indoor air purification area of approximately $0.6 \mathrm{~m}^{2}$ (Figure 2). The vegetation panel of the system has a multi-layered structure with three $50 \mathrm{~mm}$ active carbon pre-filters, and twenty-five air-purifying plants (Ficus elastica, Epipremnum aureum, and Dracaena sanderiana 'Victoria'), selected based on the findings of a previous study [31], were planted. An irrigation port was provided at the bottom of the biofilter to supply water from the storage tank to the top of the panel using a pump. The automatic control unit was connected to the supply water for irrigation according to the irrigation cycle. A fan with a low-noise EC motor (single-phase $/ 220 \mathrm{~V}$, $2510 \mathrm{rpm}, 0.17 \mathrm{~kW}$ ) was installed at the top of the biofilter, providing an air conditioning performance of up to $800 \mathrm{~m}^{3} / \mathrm{h}$ and static pressure of $380 \mathrm{~Pa}$. The applied fan offered an air-handling unit (AHU) function to the vegetation biofilter system. The polluted air is sucked in as the return air (RA) at the bottom, and purified air is supplied as the supply air (SA) at the top. The light fixture in the front of the biofilter was equipped with six LEDs (Cool White, 440-660 nm full spectrum, $0.2 \mathrm{~W}$ ) for the vegetation.

The vegetation biofilter control was set up as follows. The irrigation unit entered operation information at odd times, ensuring that $1.5 \mathrm{~L} / \mathrm{min}$ of irrigation water was supplied to the biofilter during operation. The air conditioning unit input the operation information at exact times to maintain the filtered wind speed at $0.126 \mathrm{~m} / \mathrm{s}$ and secure a filtered air volume of $177.18 \mathrm{~m}^{3} / \mathrm{h}$ while operating the biofilter. The lighting department created a light environment to maintain an average photosynthetic photon flux density of $28.5 \mu \mathrm{mol} / \mathrm{m}^{2} \mathrm{~s}$ from 6:00 to 22:00.

\subsubsection{Experimental Method}

This experiment was repeated three times, at intervals of 5 weeks from 18 April 2020 to 1 August 2020. Cycle 1 was run from 18 April to 23 May, cycle 2 from 24 May to 28 June, and cycle 3 from 27 June to 1 August. The vegetation biofilter mockup was installed from 18 April 2020 to 1 August 2020. Data of $\mathrm{PM}_{10}, \mathrm{PM}_{2.5}$, temperature, and humidity collected in the IAQ station were analyzed by dividing them into three cycles at 5-week intervals. For the system air volume analysis, the test standard SAREK A101-2011 [33] was applied mutatis mutandis within the analysis period of particulate pollutants. Face wind speed was measured using a multi-function measuring instrument (Testo 480; Testo, Titisee-Neustadt, Germany) and a wind speed probe (comfort probe 0628 0143; Testo, Titisee-Neustadt, Germany). The airflow rate was calculated according to the aforementioned test standards. Finally, the analysis of particulate pollutants was carried out by collecting samples from the center of the SA and three points of the RA, totaling four points (A, B, C, and D), over three times on the last day of each cycle. The three RA locations were classified vertically as the top (B), middle (C), and bottom (D) of the panel to determine the weight ratio of pollutants according to the wind speed difference. As for air collection, three samples were collected 
at each point, and the number of samples collected was $12(4$ areas $\times 3)$. The total number of samples collected over three cycles during the experiment period was 36 ( 3 times $\times 12$ ).
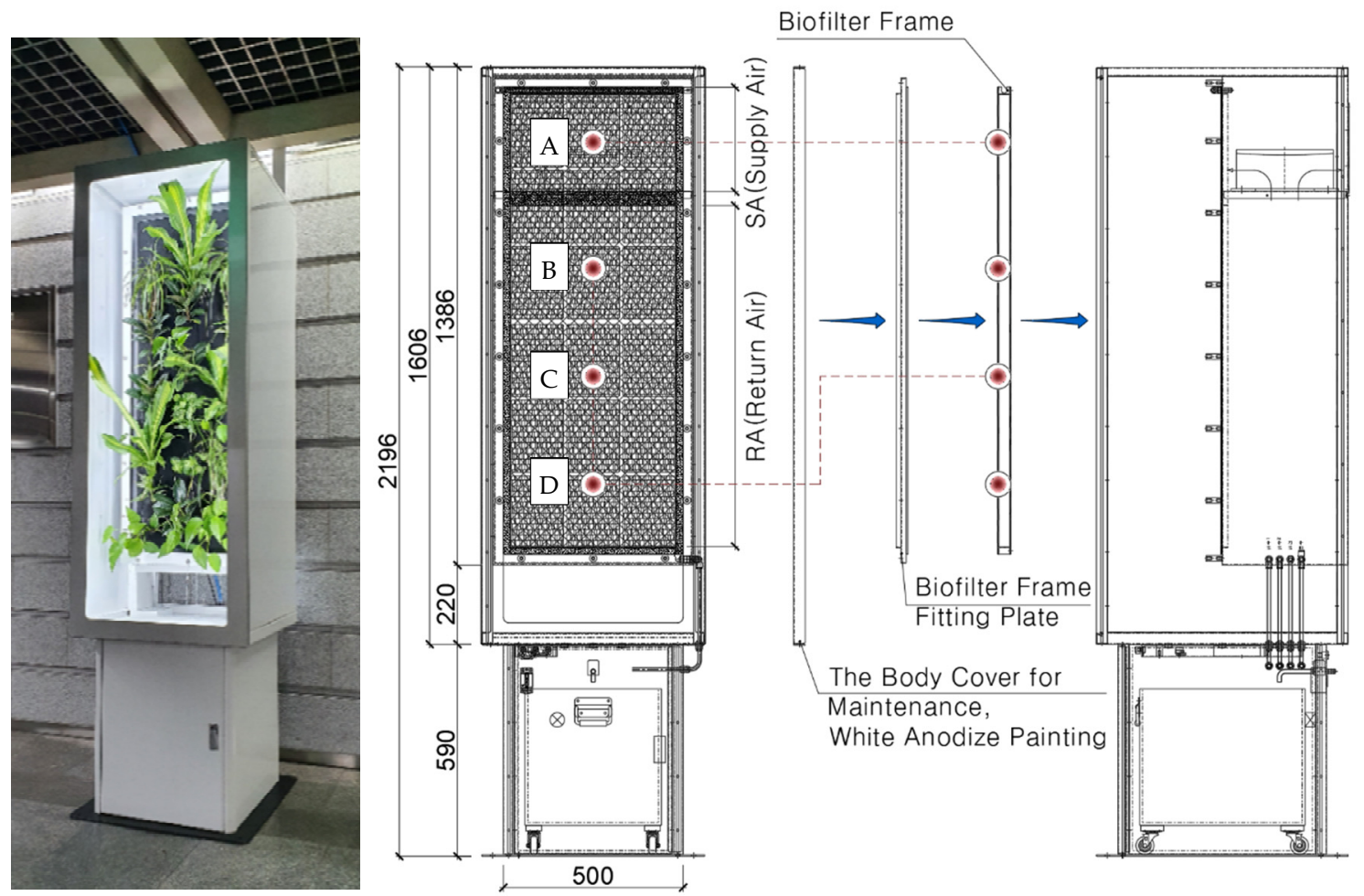

Figure 2. Vegetation biofilter and sampling location (A, supply air; B, C, D, return air).

\subsubsection{Sample and Data Analyses}

The collected samples were pre-treated by subdividing them into $5 \mathrm{~mm} \times 5 \mathrm{~mm}$ pieces and analyzed three times for each specimen by scanning electron microscopy (SEM) using a scanning electron microscope (CUBE III, Emcrafts, Gwangju-si, Gyeonggi-do, Korea) equipped with an energy-dispersive X-ray spectroscopy (EDS) apparatus (QUANTAX610X; Bruker, MA, USA). They were then dried at a humidity of less than $40 \%$ for more than 2 weeks; thereafter, they were coated with $\mathrm{Au}$ in an ion sputter coater (G20, GSEM, Seoul, Korea), for $180 \mathrm{~s}$ under a $10 \mathrm{~mA}$ current, before SEM-EDS analysis. Under the control of the Esprit Compact (Bruker, Billerica, MA, USA), the X-ray spectra were set at a $15 \mathrm{kV}$ accelerating voltage, WD $11-13 \mathrm{~mm}$, fixed at $100 \times$ magnification for each region, and the average weight ratio of elements detected for $300 \mathrm{~s}$ was calculated. SPSS 28.0 was used to analyze data collected from $1 \mathrm{SA}$ and $3 \mathrm{RA}$ locations. The difference before and after the experiment was analyzed using the Wilcoxon signed rank test ( $Z$ ), a non-parametric statistic, considering that the number of data points collected was nine, even though the normality test was passed.

\section{Results}

\subsection{Air Quality Analysis in the Mockup Construction Area}

The quality of the air collected during the experiment was analyzed as follows. In the area where the vegetation biofilter mockup was installed, the $\mathrm{PM}_{10}$ and $\mathrm{PM}_{2.5}$ concentrations were the highest in the second cycle $\left(\mathrm{PM}_{10}: 58.6 \mu \mathrm{g} / \mathrm{m}^{3}, \mathrm{PM}_{2.5}: 30.8 \mu \mathrm{g} / \mathrm{m}^{3}\right)$. On the contrary, the lowest concentration $\left(\mathrm{PM}_{10}: 44.8 \mu \mathrm{g} / \mathrm{m}^{3}, \mathrm{PM}_{2.5}: 23.5 \mu \mathrm{g} / \mathrm{m}^{3}\right)$ was recorded in the third cycle. The lowest indoor temperature $\left(19.9^{\circ} \mathrm{C}\right)$ was recorded in the first cycle, whereas the highest temperature $\left(27.4^{\circ} \mathrm{C}\right)$ was recorded in the third cycle, confirming that it increased by $37.7 \%$ compared with that in the first cycle (Figure 2 and Table 3 ). 
Table 3. Indoor air quality, at each experiment cycle, in the area where the vegetation biofilter was installed.

\begin{tabular}{cccccc}
\hline Date & PM & $\begin{array}{c}\mathbf{P M}_{\mathbf{1 0}} \\
\left(\boldsymbol{\mu g} / \mathbf{m}^{\mathbf{3}}\right)\end{array}$ & $\begin{array}{c}\mathbf{P M}_{\mathbf{2 . 5}} \\
\left(\boldsymbol{\mu g} / \mathbf{m}^{\mathbf{3}}\right)\end{array}$ & $\begin{array}{c}\text { Temperature } \\
\left({ }^{\circ} \mathbf{C}\right)\end{array}$ & $\begin{array}{c}\text { Relative } \\
\text { Humidity (\%) }\end{array}$ \\
\hline \multirow{2}{*}{ 1st cycle } & Mean & 49.7 & 26.1 & 19.9 & 54.6 \\
(18 April-23 May) & SD & 26.7 & 14.3 & 2.3 & 15.0 \\
& $\max$ & 208.0 & 115.0 & 24.0 & 80.6 \\
& $\min$ & 0.0 & 0.0 & 11.9 & 21.6 \\
\hline 2nd cycle & Mean & 58.6 & 30.8 & 25.2 & 63.2 \\
(24 May-28 June) & SD & 24.6 & 13.4 & 2.5 & 7.0 \\
& max & 254.0 & 150.0 & 30.5 & 82.2 \\
& min & 0.0 & 0.0 & 18.7 & 39.8 \\
\hline 3rd cycle & Mean & 44.8 & 23.5 & 27.4 & 67.7 \\
(27 June-1 August) & SD & 24.9 & 13.1 & 1.0 & 6.3 \\
& max & 210.0 & 116.0 & 29.7 & 84.3 \\
& min & 0.0 & 0.0 & 23.6 & 46.3 \\
\hline
\end{tabular}

The air flow rate of the vegetation biofilter mockup was calculated using the same technical standard, dividing SA into 25 points and RA into 35 points, and measuring the surface wind speed for each measuring point (Table 4). The image in Table 3 was created using MATLABR2019b (MathWorks, Natick, MA, USA). The maximum measured SA wind speed was $0.45 \mathrm{~m} / \mathrm{s}$, the minimum was $0.19 \mathrm{~m} / \mathrm{s}$, and the average was $0.30 \pm 0.06 \mathrm{~m} / \mathrm{s}$, resulting in a total air volume of $111.74 \mathrm{~m}^{3} / \mathrm{h}$. The maximum measured wind speed of RA was $0.18 \mathrm{~m} / \mathrm{s}$, the minimum was $0.05 \mathrm{~m} / \mathrm{s}$, and the average was $0.30 \pm 0.03 \mathrm{~m} / \mathrm{s}$, resulting in a total air volume of $177.18 \mathrm{~m}^{3} / \mathrm{h}$. The wind speed decreased by $36.9 \%$ in SA compared with that in RA, and the wind speed decreased as it moved away from the top of the RA. Compared with the upper part $(0.134 \pm 0.03 \mathrm{~m} / \mathrm{s})$, the wind speed in the central part $(0.125 \pm 0.03 \mathrm{~m} / \mathrm{s})$ decreased by $4.8 \%$, and that in the lower part $(0.12 \pm 0.02 \mathrm{~m} / \mathrm{s})$ decreased by $11.2 \%$. This was interpreted to be caused by the different surface intake mechanisms of the RA depending on the separation distance of the air conditioning fan. In addition, the surface wind speed measurement results for each sampling point were confirmed to be at a constant level $(\mathrm{SD}=0.03-0.06)$. A homogeneous surface wind speed environment was created on the surface of the vegetation biofilter.

Table 4. Surface wind speed and total air volume of the vegetation biofilter mockup, measured based on a test standard (SAREK A101-2017).

\begin{tabular}{|c|c|c|c|c|c|c|c|c|c|c|c|c|}
\hline \multirow{2}{*}{ 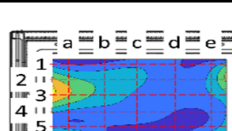 } & \multirow{2}{*}{$7_{0.4}^{0.45}$} & & \multicolumn{5}{|c|}{ Supply Air (SA) (m/s) } & \multicolumn{5}{|c|}{ Return Air (RA) (m/s) } \\
\hline & & Measuring Point & a & $\mathbf{b}$ & c & d & e & a & $\mathbf{b}$ & c & d & e \\
\hline \multirow{10}{*}{$\mid \begin{array}{ll}11 \\
1 \\
11 \\
2 \\
11 \\
3 \\
31 \\
4 \\
11 \\
11 \\
5 \\
11 \\
6 \\
61 \\
7\end{array}$} & \multirow{2}{*}{0.35} & 1 & 0.37 & 0.28 & 0.19 & 0.24 & 0.34 & 0.13 & 0.15 & 0.14 & 0.05 & 0.15 \\
\hline & & 2 & 0.29 & 0.27 & 0.28 & 0.24 & 0.30 & 0.14 & 0.13 & 0.14 & 0.13 & 0.18 \\
\hline & 0.3 & 3 & 0.45 & 0.34 & 0.29 & 0.27 & 0.33 & 0.09 & 0.10 & 0.11 & 0.15 & 0.14 \\
\hline & \multirow{2}{*}{0.25} & 4 & 0.40 & 0.33 & 0.31 & 0.26 & 0.41 & 0.10 & 0.12 & 0.10 & 0.16 & 0.18 \\
\hline & & 5 & 0.24 & 0.21 & 0.26 & 0.25 & 0.24 & 0.10 & 0.08 & 0.14 & 0.15 & 0.16 \\
\hline & 0.2 & 6 & - & - & - & - & - & 0.08 & 0.12 & 0.10 & 0.13 & 0.15 \\
\hline & \multirow{3}{*}{$\begin{array}{l}0.15 \\
0.1\end{array}$} & 7 & - & - & - & - & - & 0.10 & 0.11 & 0.13 & 0.15 & 0.12 \\
\hline & & $\operatorname{Mean}(\mathrm{m} / \mathrm{s})$ & \multirow{2}{*}{\multicolumn{5}{|c|}{$\begin{array}{l}0.30 \\
0.06\end{array}$}} & \multirow{2}{*}{\multicolumn{5}{|c|}{0.13}} \\
\hline & & $\mathrm{SD}$ & & & & & & \multirow{2}{*}{\multicolumn{3}{|c|}{$\begin{array}{c}0.03 \\
177.18\end{array}$}} & & \\
\hline & 0.05 & Air flow rate $\left(\mathrm{m}^{3} / \mathrm{h}\right)$ & \multicolumn{5}{|c|}{111.74} & & & & & \\
\hline
\end{tabular}




\subsection{Particulate Pollutant Composition Analysis \\ 3.2.1. Return Air (RA)}

Specimens were collected by cycle at three RA locations of the vegetation biofilter, and samples were collected at three points and analyzed. The average weight ratio of the main elements was calculated as follows: C (64.8 wt.\%), O (27.7 wt.\%), and Fe (4.1 wt.\%). The high $\mathrm{O}$ content was interpreted as the basis for the formation of oxides of other elements, and Fe was evenly distributed in the samples of all cycles. In addition, the elements detected with weight ratios of $1 \mathrm{wt} . \%$ or more were $\mathrm{Si}$ and $\mathrm{Ca}$ in the first cycle, $\mathrm{Cl}$ and $\mathrm{Ca}$ in the second cycle, and $\mathrm{Ca}$ in the third cycle.

Table 5 and Figure 3 present the results of element analysis for RA samples collected during the first cycle. The weight ratio of Fe collected in the first cycle (23 May) was different for each sampling point. The average weight ratio at point $\mathrm{B}(9.6 \mathrm{wt} . \%)$ was higher than that at points C (2.3 wt.\%) and D (0.4 wt.\%).

Table 5. Weight ratio for each major element of the return air, measured using SEM-EDS, on 23 May.

\begin{tabular}{|c|c|c|c|c|c|c|c|c|c|c|}
\hline \multirow{2}{*}{$\begin{array}{c}\text { Sampling } \\
\text { Area }\end{array}$} & \multicolumn{10}{|c|}{ Mean Weight Ratio (SD) (in wt.\%) } \\
\hline & $\mathrm{C}$ & $\mathbf{O}$ & Si & $\mathrm{Na}$ & Mg & $\mathrm{Cl}$ & $\mathrm{Ca}$ & $\mathbf{K}$ & Al & $\mathbf{F e}$ \\
\hline $\mathrm{B}$ & $61.8(1.3)$ & $25.5(0.6)$ & $1.1(0.1)$ & $0.1(0.2)$ & ND & $0.2(0.2)$ & $1.4(0.2)$ & $0.2(0.3)$ & ND & $9.6(0.8)$ \\
\hline $\mathrm{C}$ & $68.2(0.6)$ & $28.4(0.2)$ & ND & ND & ND & ND & $1.1(0.4)$ & ND & ND & $2.3(0.5)$ \\
\hline $\mathrm{D}$ & $69.3(0.8)$ & $29.1(0.4)$ & ND & $0.3(0.5)$ & ND & ND & $0.9(0.3)$ & ND & ND & $0.4(0.3)$ \\
\hline
\end{tabular}
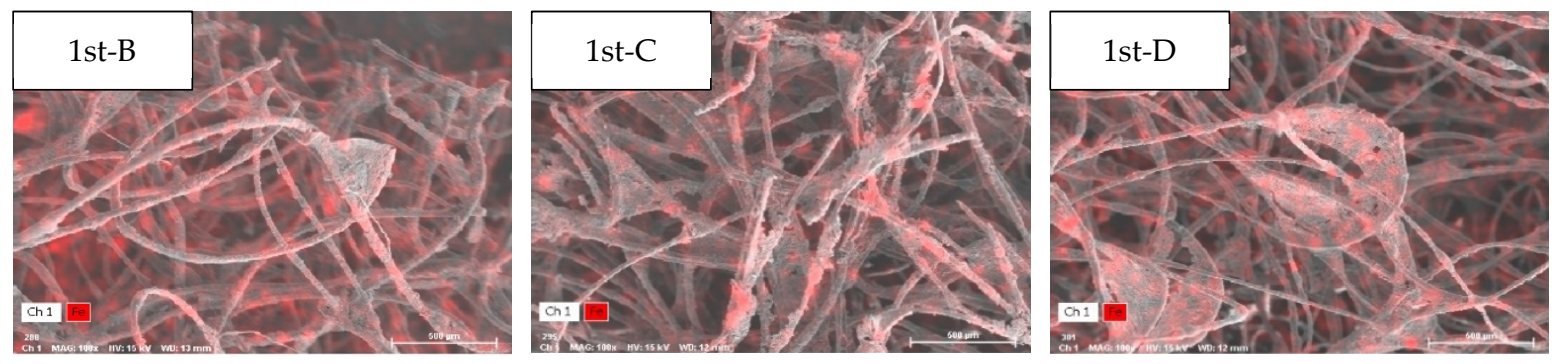

Figure 3. Element analysis of the return air through SEM-EDS on 23 May.

In the RA samples collected in the second cycle (28 June), the weight ratio of Fe was different at each sampling point: 9.6 at B, 5.5 at C, and 4.0 at D (Table 6 and Figure 4). There was also a difference from the analysis results in the data collected in the first cycle. At point $\mathrm{B}$, a weight ratio $(9.6 \mathrm{wt} . \%)$ similar to that of the first cycle was calculated. However, the weight ratios at points $C$ and $D$ increased by 1.7 and 10 times, respectively, compared to the values measured in the first cycle. In addition, $\mathrm{Cl}$ was the main element detected with $\mathrm{Ca}$, with a weight ratio of $1 \mathrm{wt} \%$ or more. In this regard, $\mathrm{Cl}$ and $\mathrm{Ca}$ were interpreted as pollutants related to the abrasion of electric cables [34].

Table 6. Weight ratio for each major element of the return air, using SEM-EDS, on 28 June.

\begin{tabular}{|c|c|c|c|c|c|c|c|c|c|c|}
\hline \multirow{2}{*}{$\begin{array}{c}\text { Sampling } \\
\text { Area }\end{array}$} & \multicolumn{10}{|c|}{ Mean Weight Ratio (SD) (in wt.\%) } \\
\hline & $\mathrm{C}$ & $\mathbf{O}$ & Si & $\mathrm{Na}$ & $\mathrm{Mg}$ & $\mathrm{Cl}$ & $\mathrm{Ca}$ & $\mathbf{K}$ & Al & $\mathrm{Fe}$ \\
\hline B & $63.8(1.0)$ & $26.0(0.6)$ & $0.3(0.4)$ & ND & ND & ND & $0.4(0.3)$ & ND & ND & $9.6(1.2)$ \\
\hline $\mathrm{C}$ & $64.3(2.1)$ & $27.5(1.3)$ & $0.3(0.5)$ & ND & ND & $0.5(0.4)$ & $1.8(0.8)$ & ND & ND & $5.5(1.8)$ \\
\hline $\mathrm{D}$ & $60.8(5.2)$ & $27.0(1.7)$ & ND & $0.9(0.0)$ & $0.3(0.4)$ & $2.3(1.4)$ & $4.4(3.5)$ & $0.3(0.4)$ & ND & $4.0(1.3)$ \\
\hline
\end{tabular}



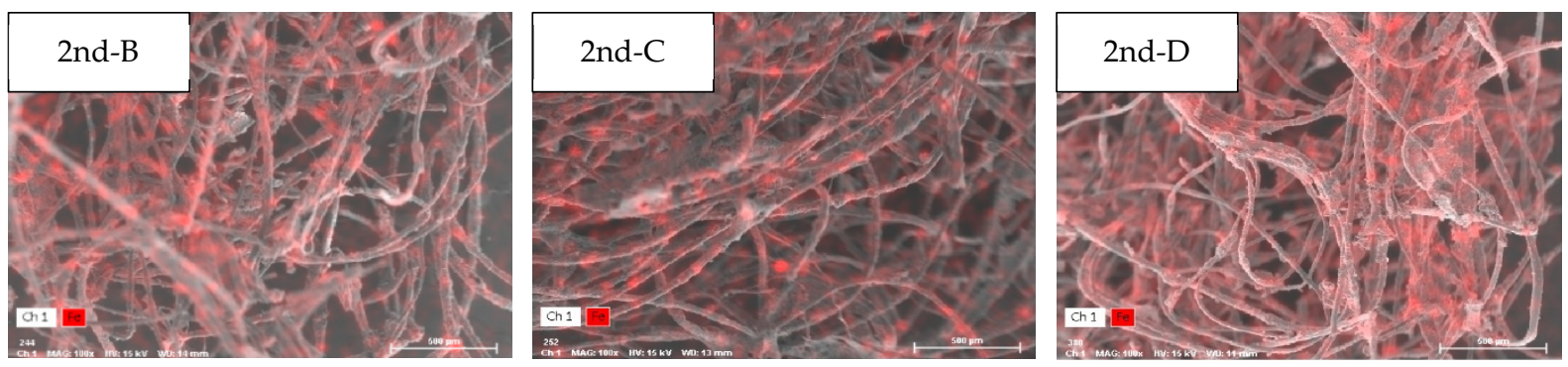

Figure 4. Element analysis of the return air, using SEM-EDS, on 28 June.

In the RA sample collected in the third cycle (1 August), the weight ratio of Fe increased (Table 7 and Figure 5), and the upper part of RA (B) recorded the highest weight ratio (11.2 wt.\%) among all cycles. The weight ratio recorded in the upper part (B) was 4.5 to 6.2 times higher than that recorded in the middle and lower parts (C and D, respectively).

Table 7. Element analysis of the return air, using SEM-EDS, on 1 August.

\begin{tabular}{|c|c|c|c|c|c|c|c|c|c|c|}
\hline \multirow{2}{*}{$\begin{array}{c}\text { Sampling } \\
\text { Area }\end{array}$} & \multicolumn{10}{|c|}{ Mean Weight Ratio (SD) (in wt.\%) } \\
\hline & $\mathrm{C}$ & $\mathbf{O}$ & Si & $\mathrm{Na}$ & Mg & $\mathrm{Cl}$ & $\mathrm{Ca}$ & $\mathbf{K}$ & Al & $\mathrm{Fe}$ \\
\hline B & $61.2(0.5)$ & $25.0(1.2)$ & ND & ND & ND & ND & $2.2(0.2)$ & ND & $0.4(0.6)$ & $11.2(0.4)$ \\
\hline $\mathrm{C}$ & $67.1(0.7)$ & $29.4(0.5)$ & ND & ND & ND & ND & $1.0(0.3)$ & ND & ND & $2.5(0.8)$ \\
\hline $\mathrm{D}$ & $67.6(0.4)$ & $27.9(0.4)$ & ND & $0.2(0.3)$ & ND & $0.6(0.4)$ & $1.9(0.3)$ & ND & ND & $1.8(0.3)$ \\
\hline
\end{tabular}
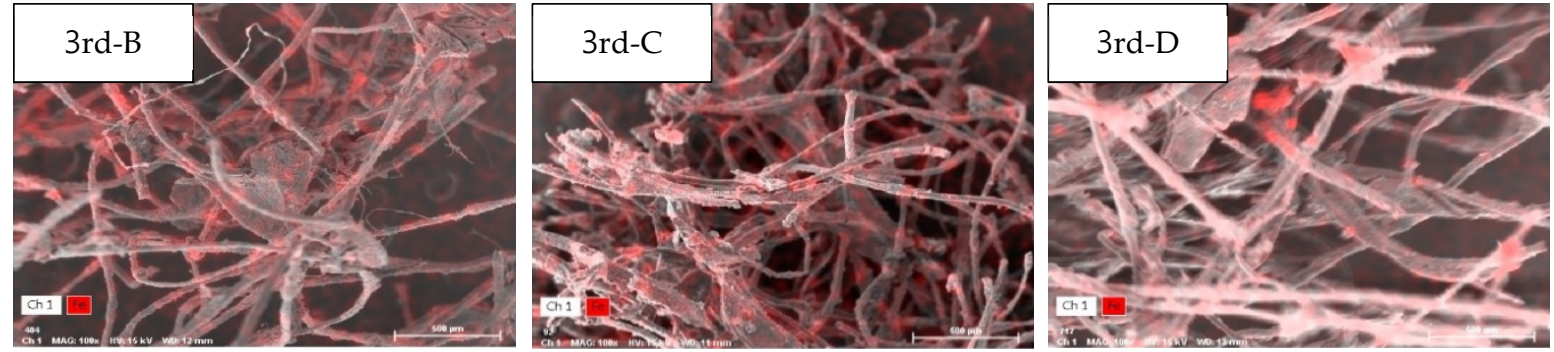

Figure 5. Element analysis of the return air, using SEM-EDS, on 1 August.

\subsubsection{Supply Air (SA)}

Samples collected from the SA center (A) of the vegetation biofilter were analyzed three times per cycle (Table 8 and Figure 6). The average weight ratio of the major elements was calculated as follows: C (62.9 wt.\%) and O (31.7 wt.\%). Fe, which was detected in a large amount in RA, had an average weight ratio ( $0.7 \mathrm{wt} . \%)$ of less than $1 \mathrm{wt} . \%$, and Ca had a partially significant weight ratio.

In the SA samples collected in the first cycle, unlike $\mathrm{C}$ and $\mathrm{O}, \mathrm{Ca}$ and $\mathrm{Cl}$ recorded a weight ratio of approximately $1 \mathrm{wt} . \%$, and in contrast to the RA samples, Fe was not detected. Even in the second cycle, the weight ratio of Ca was less than $1 \mathrm{wt} . \%$. However, $\mathrm{Fe}$, which was not detected in the first cycle, presented the highest weight ratio (1.0\% wt.\%) among the SA samples of the previous cycle. In the third cycle (1 August), in addition to C and $\mathrm{O}, \mathrm{Ca}$ had a weight ratio of $3.3 \mathrm{wt} . \%$, and Fe exhibited a decrease in the weight ratio compared with that in the second cycle (0.4 wt.\%). 
Table 8. Element analysis of the supply air, using SEM-EDS.

\begin{tabular}{|c|c|c|c|c|c|c|c|c|c|c|}
\hline \multirow{2}{*}{$\begin{array}{l}\text { Sampling } \\
\text { Time }\end{array}$} & \multicolumn{10}{|c|}{ Mean Weight Ratio (SD) (in wt.\%) } \\
\hline & $\mathrm{C}$ & $\mathbf{O}$ & Si & $\mathrm{Na}$ & Mg & $\mathrm{Cl}$ & $\mathrm{Ca}$ & $\mathbf{K}$ & Al & $\mathrm{Fe}$ \\
\hline 23 May & $68.2(0.6)$ & $29.9(0.4)$ & ND & ND & ND & $0.7(0.1)$ & $1.2(0.2)$ & ND & ND & ND \\
\hline 28 June & $68.0(0.3)$ & $30.3(0.3)$ & ND & ND & ND & $0.0(0.0)$ & $0.7(0.0)$ & ND & ND & $1.0(0.1)$ \\
\hline 1 August & $65.3(1.8)$ & $31.1(0.4)$ & ND & ND & ND & $0.0(0.0)$ & $3.3(1.2)$ & ND & ND & $0.4(0.3)$ \\
\hline
\end{tabular}

Note: The data are of a sample collected at the midpoint of the supply air.
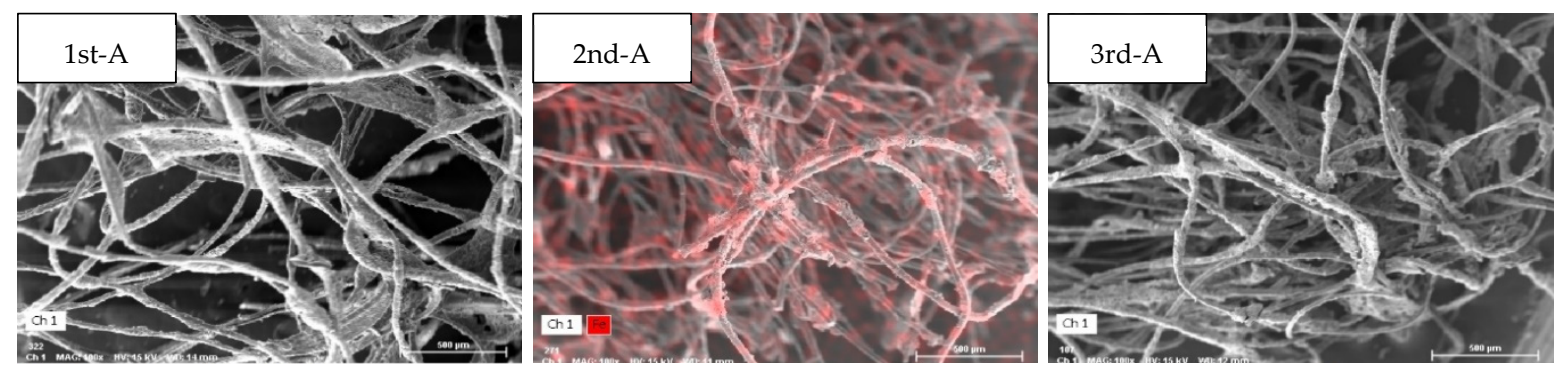

Figure 6. Element analysis of the supply air, using SEM-EDS, on 23 May, 28 June, and 1 August.

\subsection{Statistical Analysis}

Specimens were collected at three times, over the course of 15 weeks, from the RA and SA of a vegetation biofilter installed in a subway station, and the characteristics of changes in the weight ratio of Fe detected in the samples are summarized below (Figure 7). The Fe weight ratio of RA was 4.11, 6.37, and 5.20 for 23 May, 28 June, 1 August, respectively These weight ratios decreased to $0.26,0.79$, and 0.71 in SA, respectively. The difference in the mean iron weight ratio was statistically significant in all cycles (Table 9).

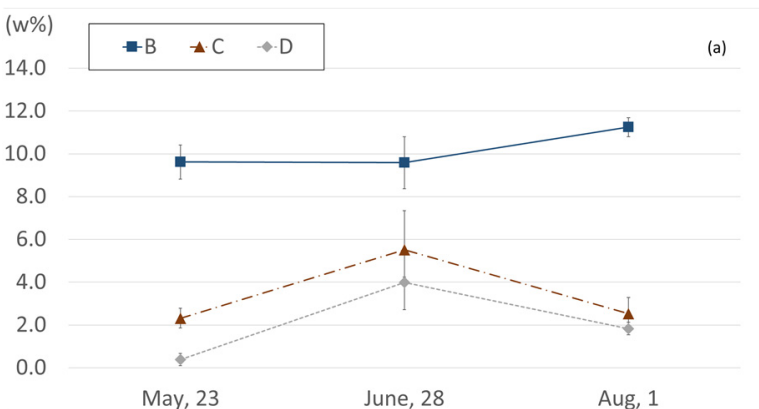

(a)

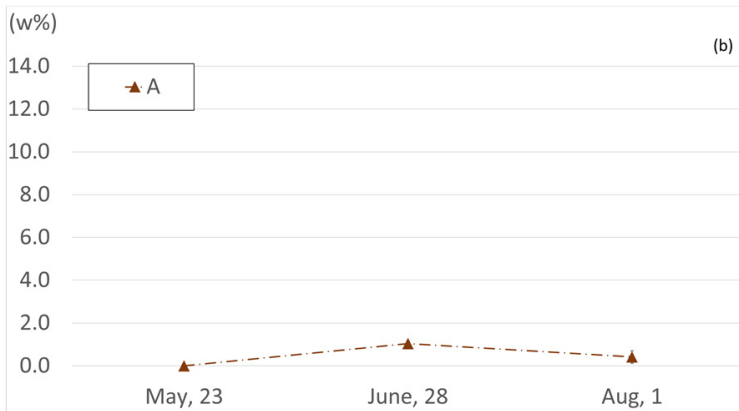

(b)

Figure 7. Change in Fe weight ratio, according to cycle: (a) sampling areas B, C, and D; (b) sampling area A.

Table 9. Statistical analysis of the difference in the weight ratio of Fe in the supply air and return air.

\begin{tabular}{ccccccc}
\hline & \multicolumn{2}{c}{ RA } & \multicolumn{2}{c}{ SA } & Z & p \\
\cline { 2 - 5 } & Mean & SD & Mean & SD & & 0.021 \\
\hline $\begin{array}{c}\text { 1st cycle } \\
\text { (18 April-23 May) }\end{array}$ & 4.11 & 4.26 & 0.26 & 0.39 & -2.31 & 0.008 \\
\hline $\begin{array}{c}\text { 2nd cycle } \\
\text { (24 May-28 June) }\end{array}$ & 6.37 & 2.95 & 0.79 & 0.51 & -2.67 & 0.008 \\
\hline $\begin{array}{c}\text { 3rd cycle } \\
\text { (29 June-1 August) }\end{array}$ & 5.20 & 4.58 & 0.71 & 0.48 & -2.66 & \\
\hline
\end{tabular}




\subsection{Comprehensive Analysis}

Figure 8 presents micrographs of typical Fe particles observed in the SA and RA of the vegetation biofilter. There were substantial differences in size, morphology, and composition among the samples collected. In sample B, Fe was the most abundant element at 71.32 wt.\% (SD = 17.45); a similarly high Fe content was detected in samples C and D. Individual analyses suggested that this was due to the presence of iron oxides, such as $\mathrm{FeO}, \mathrm{Fe}_{2} \mathrm{O}_{3}$, and magnetite $\mathrm{Fe}_{3} \mathrm{O}_{4}$, where $\mathrm{Fe}$ is mainly bound to $\mathrm{O}_{2}$. This observation is similar to that of a previous study [35]. The present study confirms the composition of Fe and partially detected metallic iron particles in the underground station. However, in sample A, Fe was detected at a trace amount of $1.44 \mathrm{wt} . \%(\mathrm{SD}=1.06)$. The Fe content in this sample was different from that in RA samples, and this change in the Fe weight ratio was identified as the cause of the change in the composition of Fe particles that passed through the vegetation biofilter.

$\mathrm{Al}$ and $\mathrm{Si}$, in addition to $\mathrm{C}$ and $\mathrm{O}$, were found in most large- and medium-sized $\mathrm{Fe}$ particles; they were also confirmed as being bound to various alkaline or alkaline earth metals, such as $\mathrm{Na}, \mathrm{K}, \mathrm{Mg}$, and $\mathrm{Ca}$ (Table 10). Several Fe-containing particles were found in the $\mathrm{PM}_{10}$ fraction. The sources of these particles include soil, road dust, weathered building materials, and geological materials, such as the gravel used on the rails [36]. $\mathrm{Cl}$ was also found at a significant weight ratio at sampling point $\mathrm{C}$, as confirmed by the previous mapping analysis. The presence of both $\mathrm{Cl}$ and $\mathrm{Ca}$ can be attributed to a railway technology research project [37]; the abrasion of electric cables can be interpreted as the source of $\mathrm{Cl}$ and $\mathrm{Ca}$ in the underground station. In addition, some trace metals such as $\mathrm{Mn}$ were detected via individual analysis.
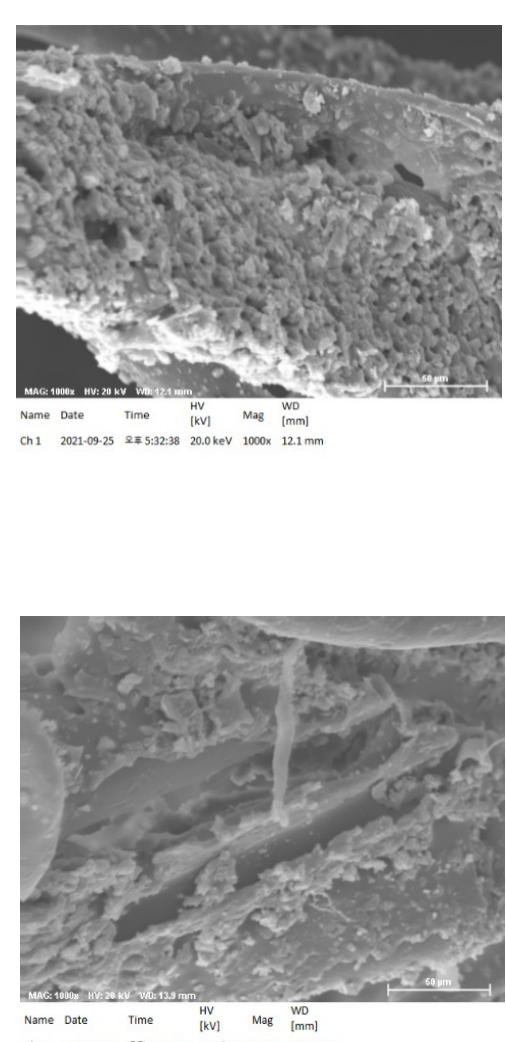

Name Date Time $\underset{[\mathrm{kV}]}{\mathrm{HV}}$ Mag $\underset{[\mathrm{mm}]}{\mathrm{W}}$

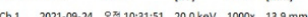

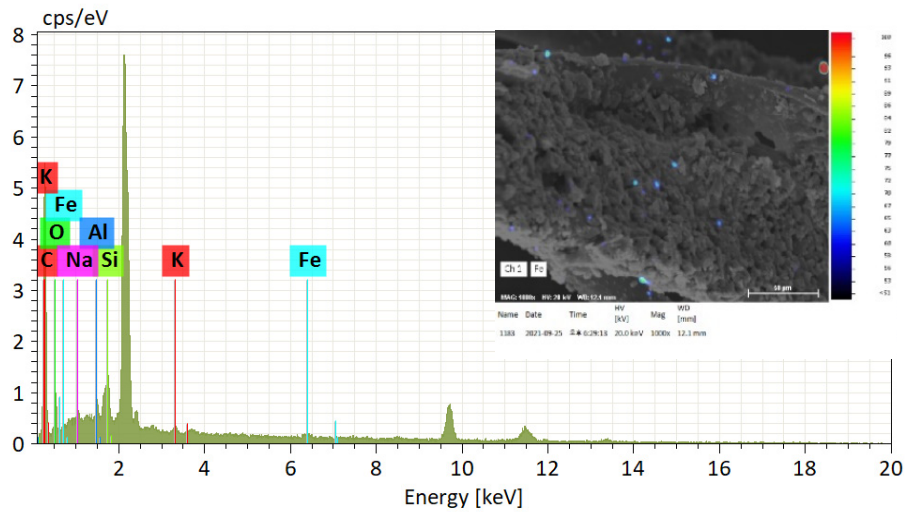

(a)

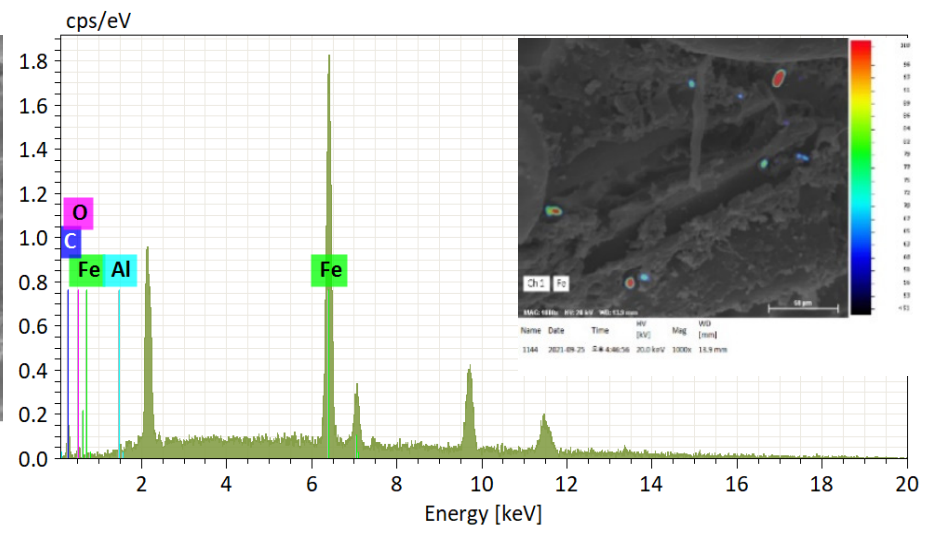

(b)

Figure 8. Cont. 

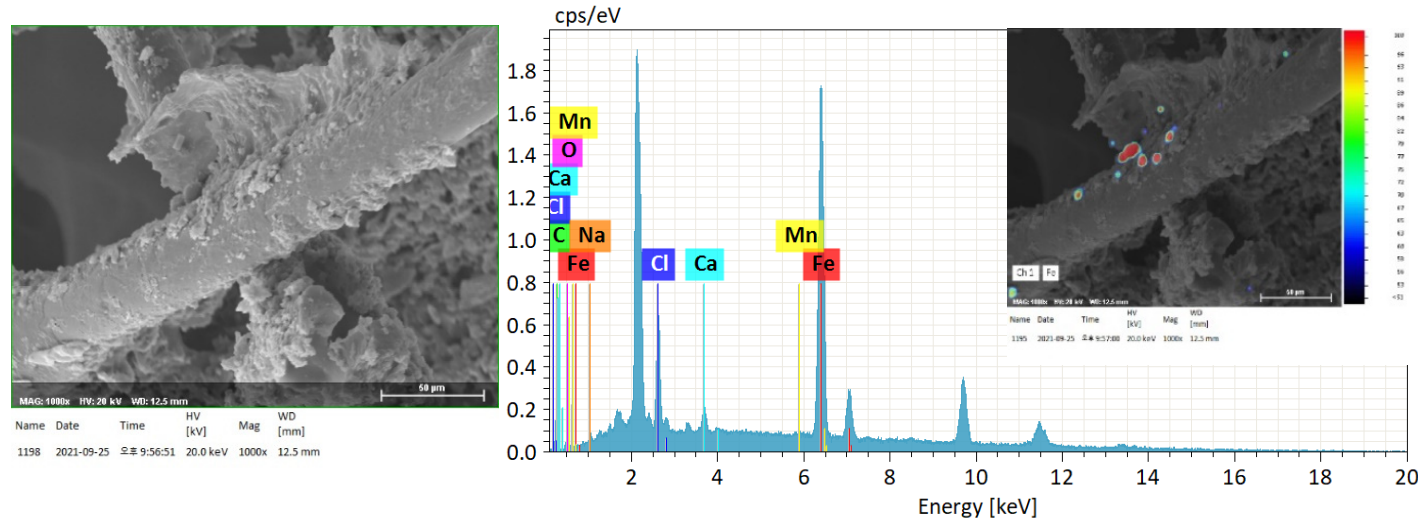

(c)
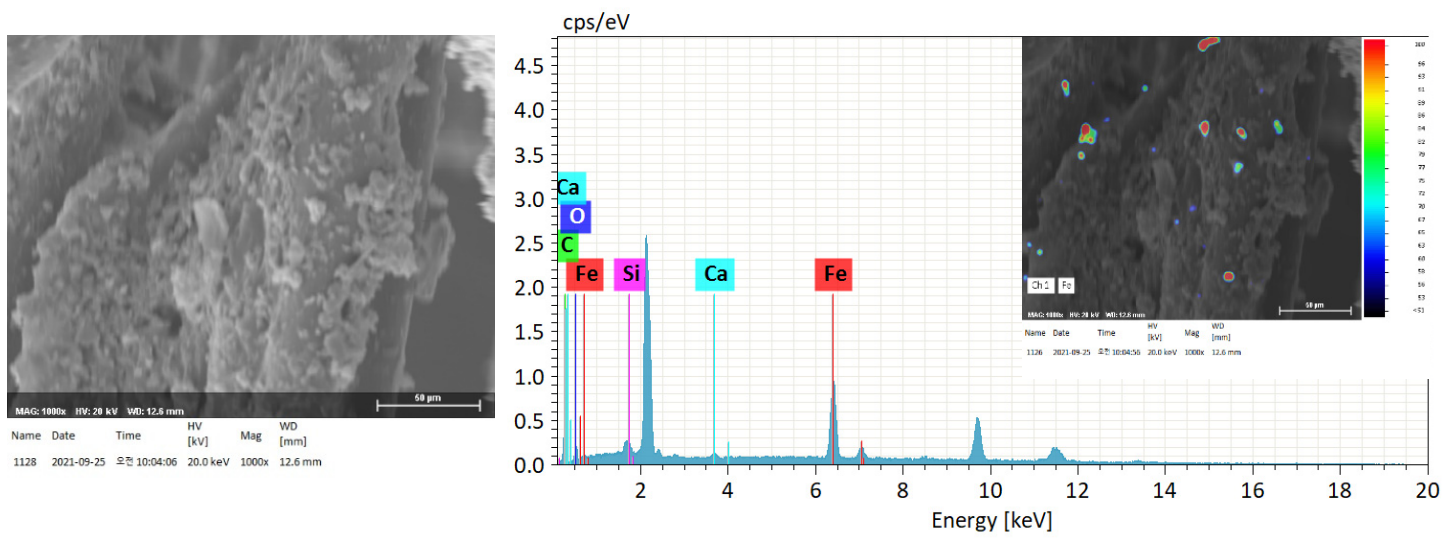

(d)

Figure 8. Scanning electron microscope photomicrographs and energy-dispersive $\mathrm{X}$-ray spectroscopy analysis of typical Fe particles: (a) sampling area A; (b) sampling area B; (c) sampling area C; (d) sampling area D.

Table 10. Energy-dispersive X-ray spectroscopy analysis of equivalent circle diameters $(\mu \mathrm{m})$ and weight ratios ( $w \mathrm{t} \%$ ) of typical Fe particles in the supply air (SA) and return air (RA).

\begin{tabular}{cccccc}
\hline \multirow{2}{*}{ Sampling Area } & SA & \multicolumn{3}{c}{ RA } & D \\
\cline { 2 - 5 } & A & B & C & $19.88(17.02)$ \\
\hline $\begin{array}{r}\text { Equivalent circle diameter } \\
(\text { ECD, } \mu \mathrm{m})(\mathrm{SD})\end{array}$ & $6.79(3.70)$ & $13.13(2.00)$ & $8.07(2.14)$ & \\
\hline & $\mathrm{C}$ & $72.12(2.03)$ & $14.95(6.68)$ & $32.02(3.84)$ & $53.32(10.28)$ \\
& $\mathrm{O}$ & $23.70(1.74)$ & $2.17(0.83)$ & $11.01(6.73)$ & $14.41(4.00)$ \\
& $\mathrm{Fe}$ & $2.48(2.35)$ & $71.32(17.45)$ & $37.14(17.73)$ & $30.29(12.3)$ \\
Mean weight & $\mathrm{Na}$ & $0.37(0.27)$ & $\mathrm{ND}$ & $8.45(5.50)$ & $\mathrm{ND}$ \\
ratio (SD) & $\mathrm{Mg}$ & $\mathrm{ND}$ & $\mathrm{ND}$ & $0.42(0.59)$ & $\mathrm{ND}$ \\
(in wt.\%) & $\mathrm{Al}$ & $0.22(0.32)$ & $9.45(7.39)$ & $0.89(0.71)$ & $\mathrm{ND}$ \\
& $\mathrm{Ca}$ & $\mathrm{ND}$ & $0.64(0.91)$ & $1.71(0.31)$ & $1.37(0.41)$ \\
& $\mathrm{Si}$ & $0.92(1.12)$ & $2.19(3.09)$ & $0.91(1.29)$ & $0.61(0.86)$ \\
& $\mathrm{Cl}$ & $\mathrm{ND}$ & $\mathrm{ND}$ & $6.74(0.77)$ & $\mathrm{ND}$ \\
& $\mathrm{Mn}$ & $\mathrm{ND}$ & $\mathrm{ND}$ & $0.25(0.35)$ & $\mathrm{ND}$ \\
& $\mathrm{K}$ & $0.18(0.25)$ & $\mathrm{ND}$ & $\mathrm{ND}$ & $\mathrm{ND}$ \\
\hline
\end{tabular}

\section{Discussion}

In this study, the IAQ in an underground station, a representative multi-use facility, was analyzed with a focus on the particulate pollutant composition because the negative effects of metallic particle contamination have been increasingly emphasized by studies, including a study that estimated the cancer risk of $\mathrm{PM}_{10}$-bound metals collected in a Seoul 
subway cabin [38] and a study on the effect of excessive Fe exposure on immune function, with respect to the suppression of the antibody production capacity of the individual [11].

In this survey, the air quality of an underground station was monitored; the main components of the air were $\mathrm{C}, \mathrm{O}$, and Fe. Similar to the results of the current study, elemental analysis of PM in a study using SEM-EDS revealed that $\mathrm{C}, \mathrm{O}$, and Fe were mainly present in the indoor air of underground stations [39-41]. In the current study, the high $\mathrm{O}_{2}$ content was interpreted as the basis for the formation of oxides of the detected elements, based on compositional surface analysis by X-ray photoelectron spectroscopy (XPS). Fe in the atmosphere of underground stations is considered to be produced by mechanical friction between rails and wheels. A previous study [34] analyzed the Fe content in particulate pollutants $(<2.5 \mu \mathrm{m})$ collected from the floor of an underground station in Seoul; the results suggested that there was a high Fe content $(70.1 \%-70.9 \%)$ in the railroad ties in tunnels and platforms, where mechanical friction is a common feature. Furthermore, a high Fe content $(14.2 \%-20.4 \%)$ was found on platforms and in ticket offices; this meant that the content of Fe detected was significantly higher than expected, supporting the aforementioned result. Moreno et al. found that $\mathrm{PM}_{10}$ containing Fe around subway station platforms and tunnels contained a mixture of ferrous metals $(\alpha-\mathrm{Fe})$, magnetite $\left(\mathrm{Fe}_{3} \mathrm{O}_{4}\right)$, maghemite $\left(\gamma-\mathrm{Fe}_{2} \mathrm{O}_{3}\right)$, and hematite $\left(\alpha-\mathrm{Fe}_{2} \mathrm{O}_{3}\right)$. The Fe metal detected was generally an oxide [42]. The particle morphology of brake flakes detected in outdoor spaces is generally irregular and exhibits a moss-like surface, which is different from the typical spherical shape of industrial fly ashes [43]. The typical Fe particles that we observed were also of irregular shapes with a moss-like surface, which were different from industrial fly ashes and were considered to be atypical brake flakes generated by friction.

In addition to $\mathrm{Fe}$, major elements over $1 \mathrm{wt} \%$ are $\mathrm{Si}$ and $\mathrm{Ca}$, as reported by a previous study on underground history [34]. Si is inferred as a geological material, and Ca is considered to originate from soil or materials used to construct underground station tunnels. In addition, in the third cycle, $\mathrm{Cl}$ was detected as a major element at $1 \mathrm{wt} . \%$ or more in addition to $\mathrm{Ca}$. $\mathrm{Cl}$, along with $\mathrm{Ca}$, was interpreted as a source of contamination related to electrical cable wear.

Plant-based remediation studies of metallic particulate pollutants have mainly focused on the adsorption function of leaves. Weerakkody et al. [44] analyzed $\mathrm{PM}_{1}, \mathrm{PM}_{2.5}$, and $\mathrm{PM}_{10}$ collected on living walls on the road using energy-dispersive X-ray spectroscopy (EDX). They found that the coniferous or small leaf species have the highest number of pollutants of all particle sizes. A study conducted in Norway and Poland investigated the PM-trapping effect of trees and shrubs [28]. Plants reduce PM through the adsorption function, and it has been reported that the amount of PM adsorption varies by species by 10 to 15 times depending on the leaf characteristics and wax content. However, the adsorption of PM by such plant leaves has limited characteristics in terms of the moisture environment. A study conducted in Beijing analyzed PM accumulation in the leaves of plant species with different epicuticular wax ultrastructures [36]. In this study, the necessity of leaf surface cleaning, such as rainfall, for continuous PM accumulation was identified using a field-emission scanning electron microscope (FE-SEM). In relation to the reduction in particulate pollutants, this study was intended to focus on the change in the average median ratio of specific elements found in vegetation media linked to air conditioning and irrigation systems, in addition to the limited adsorption function of plants suggested in previous studies.

Air purification research prioritizing vegetation media has primarily focused on the effect of reducing gaseous pollutants. Wang et al. [29] investigated the pollutant removal efficiency of a DBAF system integrated with an HVAC facility in a $96.8 \mathrm{~m}^{2}$ office. When the volumetric water content of the root bed was $5 \%-32 \%$, the DBAF system, a hydroponic planter based on activated carbon, was effective in removing both formaldehyde and toluene. When the effect of reducing pollutants in vegetation media is related to HVAC facilities, a review of the airflow rate in addition to the moisture content is required. In a study of the methyl ethyl ketone reduction effect of active biofiltration (Naava One system, 
Naturvention Pty, Jyväskylä, Finland) [22], the reduction performance corresponding to $56.6 \% \pm 0.86 \%$ single-pass efficiency (SPE) and a $28.3 \mathrm{~m}^{3} / \mathrm{h}$ clean air delivery rate (CADR) was monitored in a $30 \mathrm{~m}^{3}(4.0 \mathrm{~m} \times 3.0 \mathrm{~m} \times 2.5 \mathrm{~m}$ high $)$ experimental chamber. Here, the airflow rate applied to the filter purification test was $50 \pm 2 \mathrm{~m}^{3} / \mathrm{h}$, a ventilation amount corresponding to 1.67 air changes per hour $(\mathrm{ACH})$. In this study, the air flow rate of the vegetation biofilter was measured by applying SAREK A101-2011 [33], a measurement standard, and the results were confirmed as RA $177.18 \mathrm{~m}^{3} / \mathrm{h}$ and SA $111.74 \mathrm{~m}^{3} / \mathrm{h}$. This is insufficient for the amount of air conditioning required for an open underground station. Therefore, this could be interpreted as the reason why the system was directly affected by the background concentration.

Iron particles exert a wide range of effects on the human body through oxidative stress. Therefore, it is an important health problem for residents of urban areas where traffic and the amount of PM are increasing, and the use of multiple underground facilities is active. In a study by Karlsson et al. [40], subway particles were more genotoxic than any other particle type because they caused cell death by mitochondrial depolarization. For this reason, the regulation of PM in the subterranean space should be shifted to the regulation of PM in the form combined with the deposited form of minerals that cause oxidative stress, not just the regulation of the amount. In addition, the air purifier's effectiveness should be verified by the extent to which it can reduce these metallic substances. In relation to the negative effects of metallic PM on the human body, in this study, we confirmed the change in the weight ratio of Fe due to the vegetation biofilter.

This was a pilot study to confirm the possibility of reducing heavy metals, which may have a detrimental effect on the human body if accumulated for a long period, using an eco-friendly biofilter. Through this study, the possibility of reducing harmful particulate substances using a biofilter was confirmed. However, our study has some limitations. First, it was not possible to confirm whether the air quality was sufficiently improved to not have a negative effect on the human body. This should be confirmed through follow-up studies. Second, as of 2021, the air volume of air conditioners installed for ventilation in the study area (second floor of the station) is $12,698 \mathrm{~m}^{3} / \mathrm{min}$ in total. When calculated with the air conditioning air volume of the vegetation biofilter set in this study, it should be approximately 7000 units. With this number, it is difficult to prove the usefulness of the current vegetation biofilter. Therefore, although the vegetation biofilter has the effect of reducing particulate matter, in order to be economically effective, a study on the maximum air conditioning air volume of the vegetation biofilter should be carried out.

\section{Conclusions}

In this study, the effect of vegetation biofilters in reducing metallic particulate pollutants originating from underground stations, which are a representative multi-use facility, was confirmed through elemental unit analysis based on SEM-EDS. The air purification ability of the aforementioned vegetation biofilter system that uses eco-friendly plants requires further studies to increase its effectiveness. The research results can be summarized as follows. $\mathrm{C}, \mathrm{O}$, and Fe were detected at high mass ratios as major elements in particulate pollutants collected from RA of vegetation biofilters installed in an underground station, and we confirmed the presence of metal oxides in subway air. In the vegetation biofilter, different surface wind speeds were employed according to the distance from the air conditioning fan, and the speed of wind decreased as it moved away from the top. Such different surface wind speeds made the content of $\mathrm{Fe}$ in the air differ at each collection point. In other words, the average weight ratio of Fe was found to be higher in the upper part of RA, which is close to the air conditioning fan, than the middle and lower parts regardless of the period. It was confirmed that $\mathrm{Fe}$, which was detected in a large amount in RA of the vegetation biofilter, decreased to an average weight ratio of less than $1 \%$ in SA. This confirmed the iron oxide reduction effect of the vegetation biofilter, but whether it has a significant effect on human health should be verified in a future study. 
An additional topic to be discussed in relation to this study is whether the decreased metallic particulate pollutants continue to exist in the irrigation water and increase the Fe content in the water, and whether the reduced pollutants are accumulated in the plants of the biofilter. To this end, additional research on the physicochemical behavior characteristics of pollutants present in plants is required, and through this, the possibility of air quality improvement by plant-based air purification systems in multi-use facilities can be more clearly identified.

Author Contributions: Conceptualization, data curation, writing-original draft preparation, writing - review and editing, T.-H.K., B.-H.C., M.-S.K. and H.-J.L.; formal analysis, investigation, validation, visualization, T.-H.K. and B.-H.C.; supervision, project administration, funding acquisition, T.-H.K. All authors have read and agreed to the published version of the manuscript.

Funding: This work was carried out with the support of "Cooperative Research Program for Agriculture Science and Technology Development (Project No. PJ014270042021)" Rural Development Administration, Korea.

Institutional Review Board Statement: Not applicable.

Informed Consent Statement: Not applicable.

Data Availability Statement: All data of this study are available from the first author on request.

Conflicts of Interest: The authors declare no conflict of interest.

\section{References}

1. International Agency for Research on Cancer. Air Pollution and Cancer; WHO: Geneva, Swiss, 2013; pp. 7-8.

2. Kim, Y. Particulate Matter in Subway Stations, Strictly Controlled. A Report from the Ministry of Environment 2018. Available online: http:/ / www.me.go.kr/home/web/board / read.do?boardMasterId=1\&boardId=850180\&menuId=286 (accessed on 29 July 2021).

3. Karlsson, H.L.; Nilsson, L.; Möller, L. Subway particles are more genotoxic than street particles and induce oxidative stress in cultured human lung cells. Chem. Res. Toxicol. 2005, 18, 19-23. [CrossRef]

4. Karlsson, H.L.; Ljungman, A.G.; Lindbom, J.; Möller, L. Comparison of genotoxic and inflammatory effects of particles generated by wood combustion, a road simulator and collected from street and subway. Toxicol. Lett. 2006, 165, $203-211$. [CrossRef] [PubMed]

5. Jung, H.; Kim, B.; Ryu, J.; Maskey, S.; Kim, J.; Sohn, J.; Ro, C. Source identification of particulate matter collected at underground subway stations in Seoul, Korea using quantitative single-particle analysis. Atmos. Environ. 2010, 44, 2287-2293. [CrossRef]

6. Liu, W. Nanoparticles and their biological and environmental applications. J. Biosci. Bioeng. 2006, 102, 1-7. [CrossRef] [PubMed]

7. Penn, S.G.; He, L.; Natan, M.J. Nanoparticles for bioanalysis. Curr. Opin. Chem. Biol. 2003, 7, 609-615. [CrossRef] [PubMed]

8. Gaharwar, U.S.; Meena, R.; Rajamani, P. Iron oxide nanoparticles induced cytotoxicity, oxidative stress and DNA damage in lymphocytes. J. Appl. Toxicol. 2017, 37, 1232-1244. [CrossRef] [PubMed]

9. Könczöl, M.; Ebeling, S.; Goldenberg, E.; Treude, F.; Gminski, R.; Gieré, R.; Grobéty, B.; Rothen-Rutishauser, B.; Merfort, I.; Mersch-Sundermann, V. Cytotoxicity and genotoxicity of size-fractionated iron oxide (magnetite) in A549 human lung epithelial cells: Role of ROS, JNK, and NF-kB. Chem. Res. Toxicol. 2011, 24, 1460-1475. [CrossRef]

10. Williams, L.J; Zosky, G.R. The inflammatory effect of iron oxide and silica particles on lung epithelial cells. Lung 2019, 197, 199-207. [CrossRef]

11. Roy, D.; Ahn, S.H.; Lee, T.K.; Seo, Y.-C.; Park, J. Cancer and non-cancer risk associated with PM10-bound metals in subways. Transp. Res. D Transp. Environ. 2020, 89, 102618. [CrossRef]

12. Wang, Z.; Qu, G.; Su, L.; Wang, L.; Yang, Z.; Jiang, J.; Liu, S.; Jiang, G. Evaluation of the biological fate and the transport through biological barriers of nanosilver in mice. Curr. Pharm. Des. 2013, 19, 6691-6697. [CrossRef]

13. Maher, B.A.; Ahmed, I.A.M.; Karloukovski, V.; MacLaren, D.A.; Foulds, P.G.; Allsop, D.; Mann, D.M.A.; Torres-Jardón, R.; Calderon-Garciduenas, L. Magnetite pollution nanoparticles in the human brain. Proc. Natl. Acad. Sci. USA 2016, 113, 10797-10801. [CrossRef] [PubMed]

14. Ward, R.J.; Zucca, F.A.; Duyn, J.H.; Crichton, R.R.; Zecca, L. The role of iron in brain ageing and neurodegenerative disorders. Lancet Neurol. 2014, 13, 1045-1060. [CrossRef]

15. Pankhurst, Q.; Hautot, D.; Khan, N.; Dobson, J. Increased levels of magnetic iron compounds in Alzheimer's disease. J. Alzheimer's Dis. 2008, 13, 49-52. [CrossRef] [PubMed]

16. Hautot, D.; Pankhurst, Q.A.; Khan, N.; Dobson, J. Preliminary evaluation of nanoscale biogenic magnetite in Alzheimer's disease brain tissue. Proc. R. Soc. B 2003, 270 (Suppl. S1), S62-S64. [CrossRef] 
17. Devos, D.; Cabantchik, Z.I.; Moreau, C.; Danel, V.; Mahoney-Sanchez, L.; Bouchaoui, H.; Gouel, F.; Rolland, A.; Duce, J.A.; Devedjian, J. Conservative iron chelation for neurodegenerative diseases such as Parkinson's disease and amyotrophic lateral sclerosis. J. Neural. Transm. (Vienna) 2020, 127, 189-203. [CrossRef]

18. Yokota, S.; Moriya, N.; Iwata, M.; Umezawa, M.; Oshio, S.; Takeda, K. Exposure to diesel exhaust during fetal period affects behavior and neurotransmitters in male offspring mice. J. Toxicol. Sci. 2013, 38, 13-23. [CrossRef] [PubMed]

19. Park, E.; Jeong, U.; Kim, Y.; Lee, B.; Cho, M.; Go, Y. Deleterious effects in reproduction and developmental immunity elicited by pulmonary iron oxide nanoparticles. Environ. Res. 2017, 152, 503-513. [CrossRef]

20. Stephens, B.; Siegel, J.A. Ultrafine particle removal by residential heating, ventilating, and air-conditioning filters. Indoor Air 2013, 23, 488-497. [CrossRef]

21. Pettit, T.; Irga, P.J.; Abdo, P.; Torpy, F.R. Do the plants in functional green walls contribute to their ability to filter particulate matter? Build. Environ. 2017, 125, 299-307. [CrossRef]

22. Torpy, F.; Clements, N.; Pollinger, M.; Dengel, A.; Mulbvihill, I.; He, C.; Irga, P. Testing the single-pass VOC removal efficiency of an active green wall using methyl ethyl ketone (MEK). Air Qual. Atmos. Health 2018, 11, 163-170. [CrossRef]

23. Irga, P.J.; Paull, N.J.; Abdo, P.; Torpy, F.R. An assessment of the atmospheric particle removal efficiency of an in room botanical biofilter system. Build. Environ. 2017, 115, 281-290. [CrossRef]

24. Llewellyn, D.; Darlington, A.; van Ras, N.; Kraakman, B.; Dixon, M. A hybridized membrane-botanical biofilter for improving air quality in occupied spaces. In Proceedings of the 37th COSPAR Scientific Assembly, Montreal, QC, Canada, 13-20 July 2008; Volume 37, p. 1813.

25. Paull, N.J.; Irga, P.J.; Torpy, F.R. Active green wall plant health tolerance to diesel smoke exposure. Environ. Pollut. 2018, 240, 448-456. [CrossRef] [PubMed]

26. Kwon, K.J.; Park, B.J. Effects of indoor greening method on temperature relative humidity and particulate matter concentration. J. Korean Inst. Landsc. Archit. 2017, 45, 1-10.

27. Lee, C.H.; Choi, B.; Chun, M.Y. Stabilizing soil moisture and indoor air quality purification in a wall-typed botanical biofiltration system controlled by humidifying cycle. Hortic. Sci. Tecnol. 2015, 33, 605-617.

28. Sæbø, A.; Popek, R.; Nawrot, B.; Hanslin, H.M.; Gawronska, H.; Gawronski, S.W. Plant species differences in particulate matter accumulation on leaf surfaces. Sci. Total Environ. 2012, 427-428, 347-354. [CrossRef]

29. Wang, Z.; Zhang, J.S. Characterization and performance evaluation of a full-scale activated carbon-based dynamic botanical air filtration system for improving indoor air quality. Build. Environ. 2011, 46, 758-768. [CrossRef]

30. Kim, T.-H.; Choi, B.-H.; Choi, N.-H.; Jang, E.-S. Particulate matter and $\mathrm{CO}_{2}$ improvement effects by vegetation-based bio-filters and the indoor comfort index analysis. Korean J. Environ. Agric. 2018, 37, 268-276. [CrossRef]

31. Soreanu, G.; Dixon, M.; Darlington, A. Botanical biofiltration of indoor gaseous pollutants-A mini-review. Chem. Eng. J. 2013, 229, 585-594. [CrossRef]

32. Kim, T.; Choi, B. Study on PM10, PM2.5 Reduction effects and measurement method of vegetation bio-filters system in multi-use facility. J. Korean Inst. Landsc. Archit. 2020, 48, 80-88. [CrossRef]

33. The Society of Air-Conditioning and Refrigerating Engineers of Korea. SAREK A101: Duct Airflow Measuring Method; SAREK: Seoul, Korea, 2011.

34. Mugica-Álvarez, V.; Figueroa-Lara, J.; Romero-Romo, M.; Sepúlveda-Sánchez, J.; López-Moreno, T. Concentrations and properties of airborne particles in the Mexico City subway system. Atmos. Environ. 2012, 49, 284-293. [CrossRef]

35. Lee, Y.; Lee, Y.; Kim, T.; Choi, J.S.; Park, D. Sources and characteristics of particulate matter in subway tunnels in Seoul, Korea. Int. J. Environ. Res. Public Health 2018, 15, 2534. [CrossRef]

36. Wang, L.; Gong, H.; Liao, W.; Zhi, W. Accumulation of particles on the surface of leaves during leaf expansion. Sci. Total Environ. 2015, 532, 420-434. [CrossRef] [PubMed]

37. Park, S.; Lee, T.; Ko, H.; Bae, S.; Kim, S.; Park, D.; Sohn, J.; Kim, D. Identification of PM $_{10}$ chemical characteristics and sources and estimation of their contributions in a Seoul metropolitan subway station. J. Korean Soc. Atmos. Environ. 2013, 29, 74-85. [CrossRef]

38. Park, E.; Kim, S.; Lee, G.; Jo, Y.; Yoon, C.; Kim, D.; Cho, J.; Han, J.; Lee, S.J.; Seong, E.; et al. Inhaled underground subway dusts may stimulate multiple pathways of cell death signals and disrupt immune balance. Environ. Res. 2020, 191, 109839. [CrossRef]

39. Jung, H.; Kim, B.; Malek, M.A.; Koo, Y.S.; Jung, J.H.; Son, Y.; Kim, J.; Kim, H.; Ro, C. Chemical speciation of size-segregated floor dusts and airborne magnetic particles collected at underground subway stations in Seoul, Korea. J. Hazard. Mater. 2012, 213-214, 331-340. [CrossRef]

40. Karlsson, H.; Holgersson, A.; Möller, L. Mechanisms related to the genotoxicity of particles in the subway and from other sources. Chem. Res. Toxicol. 2008, 21, 726-731. [CrossRef]

41. Midander, K.; Elihn, K.; Wallen, A.; Belova, L.; Karlsson, A.; Wallinder, I. Characterisation of nano-and micron-sized airborne and collected subway particles, a multi-analytical approach. Sci. Total Environ. 2012, 427, 390. [CrossRef] [PubMed]

42. Moreno, T.; Martins, V.; Querol, X.; Jones, T.; BéruBé, K.; Minguillón, M.C.; Amato, F.; Capdevila, M.; de Miguel, E.; Centelles, S.; et al. A new look at inhalable metalliferous airborne particles on rail subway platforms. Sci. Total Environ. 2015, 505, 367-375. [CrossRef] [PubMed] 
43. Sagnotti, L.; Taddeucci, J.; Winkler, A.; Cavallo, A. Compositional, morphological, and hysteresis characterization of magnetic airborne particulate matter in Rome, Italy. Geochem. Geophys. Geosyst. 2009, 10, Q08Z06. [CrossRef]

44. Weerakkody, U.; Dover, J.W.; Mitchell, P.; Reiling, K. Quantification of the traffic-generated particulate matter capture by plant species in a living wall and evaluation of the important leaf characteristics. Sci. Total Environ. 2018, 635, 1012-1024. [CrossRef] 